Primljen / Received: 27.10.2011. Ispravljen / Corrected: 18.6.2012.

Prihvaćen / Accepted: 26.6.2012. Dostupno online / Available online: 16.7.2012.

\section{Effects of stiffness reduction on seismic capacity of buildings}

Authors:

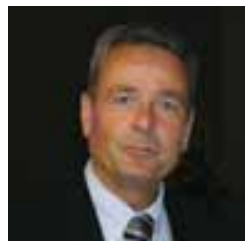

Prof. Mehmed Čaušević, Ph.D. CE

University of Rijeka

Faculty of Civil Engineering

mehmed.causevic@gradri.hr

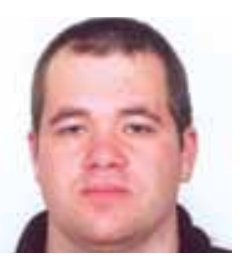

Tomislav Franković, mag. ing. aedif.

University of Rijeka

Faculty of Civil Engineering

tomislav.frankovic@gradri.hr

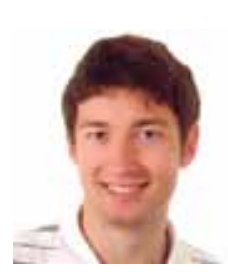

Nino Mahmutović, mag. ing. aedif.

University of Rijeka

Faculty of Civil Engineering

nino.mahmutovic@gradri.hr

\section{Mehmed Čaušević, Tomislav Franković, Nino Mahmutović}

\section{Effects of stiffness reduction on seismic capacity of buildings}

Results obtained by analysis of two typical structures are presented. The value of shear stiffness, or stiffness to bending of structural elements (beams or walls), was varied during this analysis. The following question was answered: why did European Standard EN 1998-1:2004 set the element stiffness reduction to fifty percent of the initial value, what happens if such limit is exceeded, how is the relevant load combination type influenced by stiffness reduction, and what is the difference in the quantity of reinforcement obtained according to linear methods, if the reduction of stiffness is, or is not, taken into account.

Pregledni rad

Mehmed Čaušević, Tomislav Franković, Nino Mahmutović

\section{Učinak redukcije krutosti na seizmičku otpornost gradevine}

U radu su izloženi rezultati istraživanja provedenih na dvije tipične konstrukcije, pri čemu se varirala vrijednost posmične krutosti ili krutosti na savijanje elemenata konstrukcije (greda ili zidova). Odgovoreno je na pitanja: zašto je europska norma EN 1998-1:2004 propisala redukciju krutosti elemenata na $50 \%$ početne vrijednosti, što se događa ako se prede ta granica, kako redukcija krutosti utječe na vrstu mjerodavne kombinacije opterećenja te kolika je razlika u količini armature dobivene prema linearnim metodama s uzimanjem u obzir redukcije krutosti i bez njih.

Ključne riječi:

reducirana krutost, kombinacija opterećenja, spektri odziva, granična stanja uporabivosti, nelinearnost

Übersichtsarbeit

Mehmed Čaušević, Tomislav Franković, Nino Mahmutović

\section{Effekt der Reduktion der Steifigkeit auf den seismischen Widerstand des Gebäudes}

In der Arbeit sind die Forschungsresultate angeführt, die auf zwei typischen Konstruktionen durchgeführt wurden, wobei die Wertigkeit der Schubsteifigkeit oder die Biegesteifigkeit der Elementkonstruktion (von Balken oder Wänden) variiert hat. Es wurden auf folgende Fragen Antwort gegeben: 1. Weshalb hat die europäische Norm EN 1998-1:2004 eine Reduktion der Steifigkeit der Elemente auf 50 \% des Anfangswertes vorgeschrieben? 2. Was geschieht, wenn diese Grenze überschritten wird? 3. Wie ist die Beeinflussung der Steifigkeitsreduktion auf die Art der maßgebenden Belastungskombination? 4. Wie groß ist die Differenz in der Armaturenquantität, die man mit und ohne Einbeziehung der Reduktion der Steifigkeit durch lineare Methoden erhält?

Reduzierte Steifigkeit, Belastungskombination, Antwortspektrum, Grenzzustand der Verwendbarkeit, Nichtlinearität 


\section{Introduction}

Four methods for estimating structural resistance of buildings, two linear and two non-linear, are specified in the Eurocode for the design of structures in earthquake-prone areas [1]. It is known that the non-linear behaviour of structures (behaviour factor concept) is also taken into account in linear analyses. The intention of the mentioned European standard is to take into account the non-linear behaviour of structures and the cracking of their elements during earthquakes, and to also use non-linear method for the analysis of structures. If for some reason this can not be achieved (for instance, if an appropriate software is not available), designers are advised to model structures in such a way to take into account in linear analysis only fifty percent of shear stiffness or flexural stiffness of load-bearing elements [1].

If the cracking of structural elements is taken into account, the first eigen period of the structure increases, and hence the value of seismic forces reduces, in accordance with the shape of the design spectrum [1, 2]. At that, the extent of the mentioned reduction can be such that the seismic design combination ceases to be relevant for massive concrete and masonry structures, which is different from former practices. It was therefore necessary to study the influence of stiffness reduction in load bearing elements, while retaining at the same time the behaviour factor values specified in EN 1998-1:2004.

Two different types of structural systems,both very often encountered in practice, will be analysed in the paper (Figures 1 and 2). The first structure is a traditional frame system without additional reinforced-concrete walls that would carry horizontal seismic forces. It consists of a basement, ground storey and six storeys above the ground level. It is rectangular in plan and measures $30 \times 18 \mathrm{~m}$. The structure is $30.75 \mathrm{~m}$ in height, the ground storey is $5.0 \mathrm{~m}$ in height, and the height of other storeys is $3.4 \mathrm{~m}$ (these values are indicated as they will be used in the analysis of allowable storey drifts). The load exerted on the structure consists of:permanent load, variable load, service load, and seismic load. The permanent load is formed of the selfweight of structural elements (taken into account in software used), and the load imposed by additional layers of the floor structure $\left(1.90 \mathrm{kN} / \mathrm{m}^{2}\right)$ and roof $\left(2.11 \mathrm{kN} / \mathrm{m}^{2}\right)$. The service load [3] is defined according to the planned occupancy (offices and commercial outlets - category B), and amounts to $2.4 \mathrm{kN} / \mathrm{m}^{2}$.

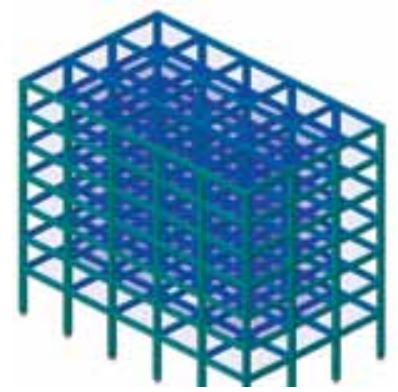

Figure 1. 3D presentation of a typical frame structure (Structure 1)
The second structure (Figure 2 ) is a frame with vertical curtain walls. It is composed of the basement, ground storey and eleven storeys above it. The structure measures $22.5 \times 22.5$ $\mathrm{m}$ in plan and reaches $50 \mathrm{~m}$ in height. The load exerted by additional layers of the floor structure and by roof is $1.5 \mathrm{kN} /$ $\mathrm{m}^{2}$ and $2.0 \mathrm{kN} / \mathrm{m}^{2}$, respectively. There are two types of service load [3, 4]: service load for office space, and service load for residential areas. The basement, ground storey and first storey are reserved for the office space with the service load of $2.4 \mathrm{kN} / \mathrm{m}^{2}$, while the remaining storeys are residential areas and their service load is $1.6 \mathrm{kN} / \mathrm{m}^{2}$.

Both structures were analysed in accordance with the Non Collapse Requirement (NCR) [1, 2]. The ductility class medium (DCM) was adonted

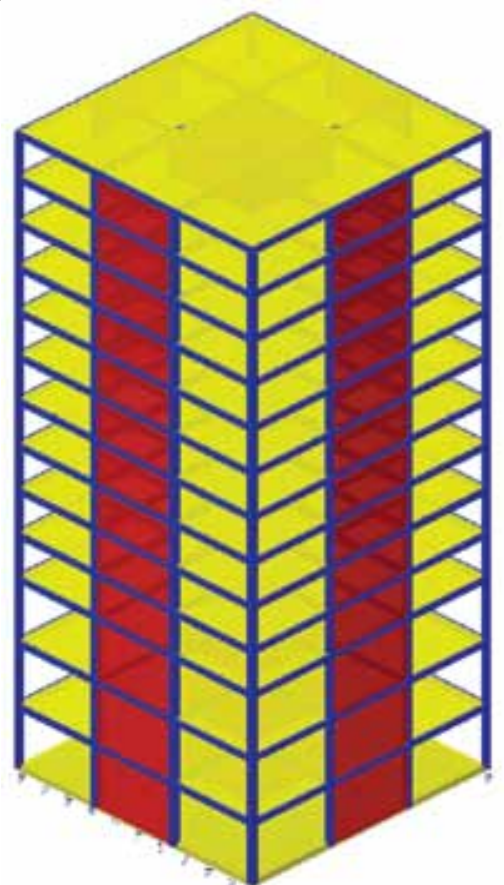

Figure 2. 3D view of a frame structure with vertical curtain walls (Structure 2)

\section{Basic assumptions for the analysis}

Properties of basic materials (concrete and reinforcing steel) must be defined before proceeding to structural analysis. The same reinforcing steel grade $\mathrm{B} 500 \mathrm{~B}$ was adopted for both structures, and the class of concrete compressive strength for the first structure is C35/45, while it is C30/37 for the second structure. Using expressions from EN 1992-1-1 [5] and an appropriate software, working diagrams for concrete were drawn in form of parabola and straight line, as shown in Figures 3 and 4. In these Figures the red line denotes the design working diagram for concrete, which was obtained by reducing the typical compressive strength (blue dotted line) by the partial safety factor for material $\gamma_{c}$. The inclination of the brown line in Figure 4 stands for the initial (tangential) modulus of elasticity $E_{0}$ (tangentni) modul elastičnosti $E_{0}$. 


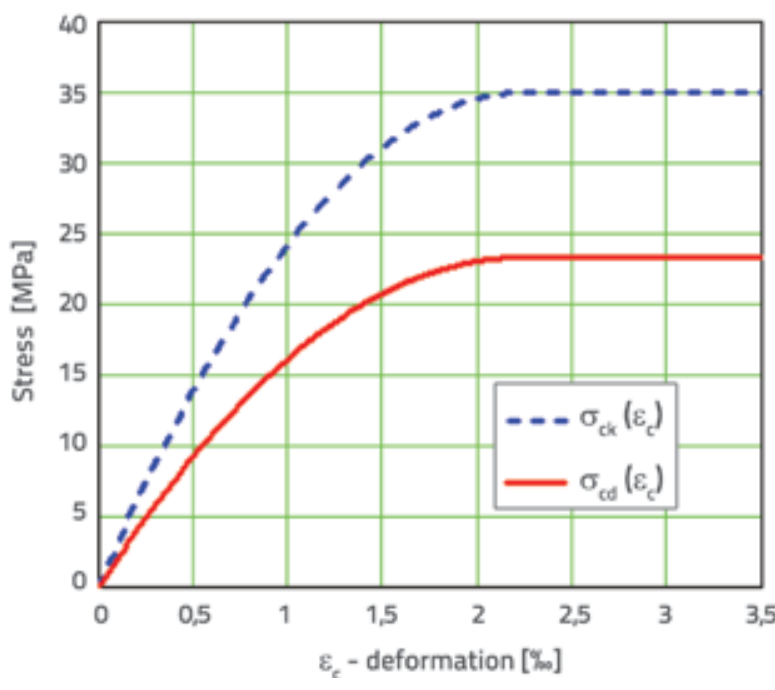

Figure 3. Design diagram for concrete C 35/45

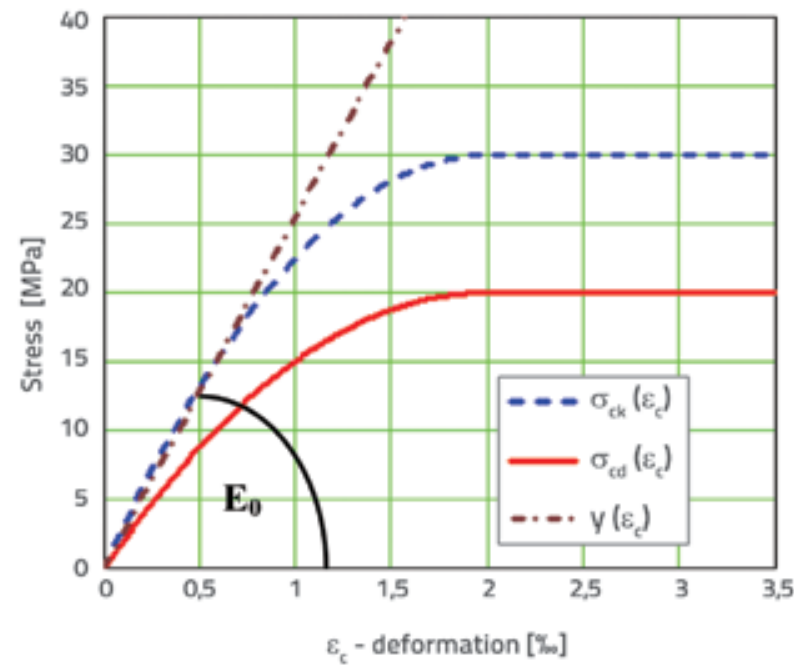

Figure 4 .Typical and design diagram for concrete C 30/37 with an initial modulus of elasticity $E_{0}$

The dimensions of structural elements were defined with the purpose of meeting design and economic requirements. The dimensions adopted are presented in Tables 1 and 2 .

Table 1 Dimensions of elements of Structure 1

\begin{tabular}{|c|c|c|c|}
\hline \multirow{2}{*}{ Element } & \multicolumn{3}{|c|}{ Dimensions } \\
\cline { 2 - 4 } & $\mathrm{b}[\mathrm{cm}]$ & $\mathrm{h}[\mathrm{cm}]$ & $\mathrm{L}[\mathrm{cm}]$ \\
\hline slab & - & 20 & 600 \\
\hline beam & 30 & 70 & 600 \\
\hline column & 60 & 60 & 500 \\
\hline
\end{tabular}

The first structure is planned at the site where the terrain is formed of loose gravel and sand deposits (foundation soil category: C), while the other structure is lies on the terrain formed of very dense sand (foundation soil category: B).

Table 2. Dimensions of elements of Structure 2

\begin{tabular}{|c|c|c|c|}
\hline \multirow{2}{*}{ Element } & \multicolumn{3}{|c|}{ Dimensions } \\
\cline { 2 - 4 } & $\mathrm{b}[\mathrm{cm}]$ & $\mathrm{h}[\mathrm{cm}]$ & $\mathrm{L}[\mathrm{cm}]$ \\
\hline slab & - & 25 & 750 \\
\hline beam & 40 & 50 & 750 \\
\hline column & 50 & 50 & 500 \\
\hline wall & 25 & $500 *$ & 750 \\
\hline \multirow{2}{*}{${ }^{*}$ Refers to the height of one storey } \\
\hline
\end{tabular}

The comparative maximum acceleration $a_{g R}$ in soil category $A$ is determined using the national addendum for the use of Eurocode 8 in Croatia [8], based on an appropriate comparative return period for seismic impact on structures, for the non collapse requirement $\mathrm{T}_{\mathrm{NCR}}=475$ years [1].

The structure importance factor depends on the structure's behaviour immediately after the earthquake, and in both cases the same value $\gamma_{1}=1.0$ was adopted. The design acceleration in category A soil can be expressed as:

$a_{g}=\gamma_{1} \cdot a_{g R}$

$a_{g}=1,0 \cdot 0,2 g=0,2 g$

Horizontal seismic actions on a given location are represented by means of an appropriate elastic acceleration response spectrum for subsoil, and are defined with two independent perpendicular components characterized by the same response spectrum, cf. Figure 5. The vertical component of seismic action is not taken into account as the condition : $a_{v g}=0,18 g<0,25 g$ has been met.

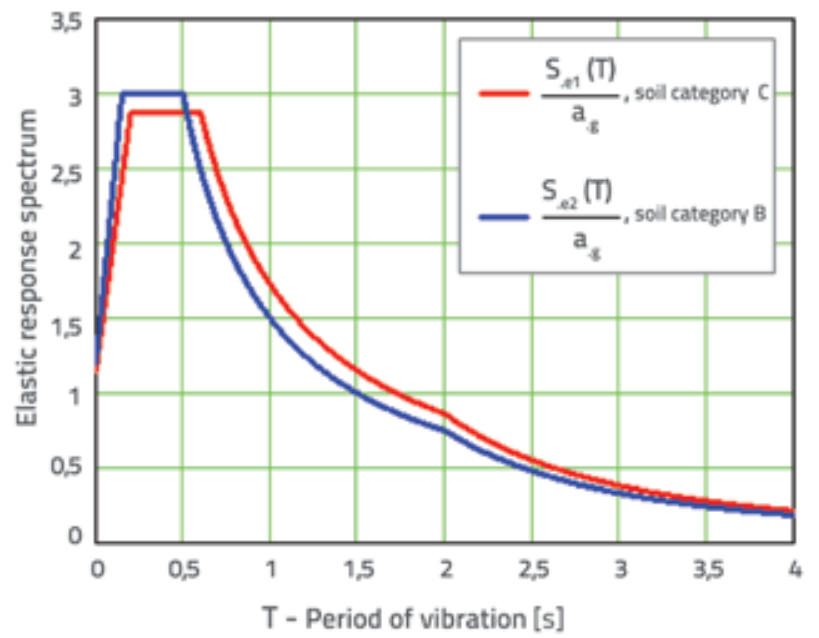

Figure 5. Elastic response spectrum (red - soil category C, blue - soil category B) 
In order to ensuretheir nonlinear behaviour, structures need to be designed for forces that are smaller than those when the structural response is fully elastic. This is realized by introducing the reduced elastic response spectrum (design spectrum, cf. Figure 6). The reduction is made through behaviour factor $q$ which is the relationship between seismic forces when structural response is fully elastic, and design seismic forces [1,2].

The behaviour factor depends of the type of structural system, and on the ductility class adopted, and is defined as follows:

$$
q=q_{0} \cdot k_{w} \geq 1,5
$$

The basic behaviour factor value $q_{0}$ is obtained from Table 3 . For multi-storey and multi-nave structures the value $\alpha_{u} / \alpha_{1}$ amounts to 1.3. The factor of dominant shape of failure $k_{w}$ is defined in Table 4.

Table 3. Basic values of behaviour factor

\begin{tabular}{|l|c|c|}
\hline Structural system & DCM & DCH \\
\cline { 1 - 2 } frame system & $3,0 \cdot \frac{\alpha_{u}}{\alpha_{1}}$ & $4,5 \cdot \frac{\alpha_{u}}{\alpha_{1}}$ \\
\cline { 1 - 2 } dual system & 3,0 & $4,0 \cdot \frac{\alpha_{u}}{\alpha_{1}}$ \\
\cline { 1 - 2 } wall system with connected walls & 2,0 & 3,0 \\
\hline wall system with disconnected walls & 1,5 & 2,0 \\
\hline torsional flexible system & & \\
\hline inverted pendulum system & & \\
\hline
\end{tabular}

Table 4 .Values of dominant shape of failure factork ${ }_{w}$

\begin{tabular}{|l|c|}
\hline Structural system & $k_{w}$ \\
\cline { 1 - 1 } frame system & 1,0 \\
\cline { 1 - 1 } wall systems similar to frame systems & \multirow{2}{*}{$0,5 \leq \frac{1+\alpha_{0}}{3} \leq 1$} \\
\cline { 1 - 1 } wall systems & \\
\hline systems similar to wall systems & \\
\hline torsional flexible systems & \\
\hline
\end{tabular}

An intermediate level of ductility, and similar basic value of behaviour factor $\left(q_{0}=3,9\right)$ and dominant shape of failure factor $\left(k_{w}=1,0\right)$, were adopted for both structures

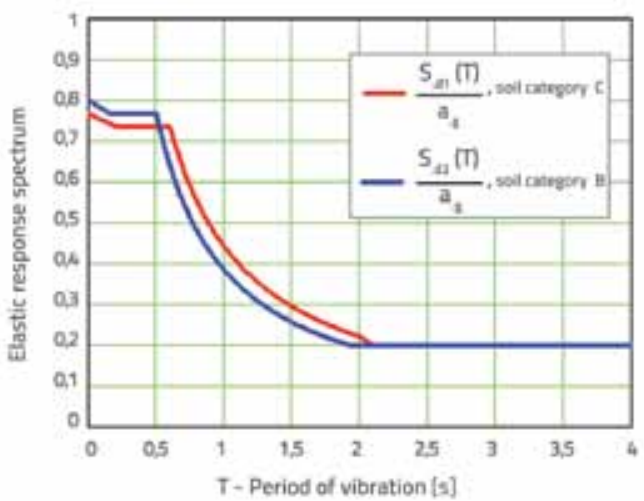

Figure 6. Design response spectrum (red - soil category C, blue - soil category B)

\section{Combinations of actions}

The structures were modelled and designed using the basic and seismic design combinations [4]. According to the basic design combination, the effects of actions are defined using the following expression:

$\sum_{j \geq 1} \gamma_{G, j} G_{k, j}{ }^{\prime \prime}+\gamma_{Q, 1} Q_{k, 1}{ }^{\prime \prime}+\sum_{i>1} \gamma_{Q, i} \psi_{0, i} Q_{k, i}$

The total weight of the structure that is "engaged" at the moment of seismic action is defined according to:

$m=\sum G_{k, j} "+" \sum \psi_{E, i} Q_{k, i}$

The combination factor $\psi_{E, i}$ is computed using the following expression:

$\psi_{E, i}=\varphi \cdot \psi_{2, i}$

where $\phi$ is the coefficient depending on the class of structure and the load exerted on individual storeys, while $\psi_{2, i}$ is the coefficient that introduces the "quasi-constant" variable action $Q_{i}$

$\Psi_{E, i}=0,5 \cdot 0,3=0,15$

The seismic design combination is based on typical values of permanent actions, reduced value of variable actions, and design value of earthquake action:

$\sum_{j \geq 1} G_{k, j} "+" P "+" A_{E d} "+" \sum_{i>1} \psi_{2, i} Q_{k, i}$

$A_{E d x}=E_{E d x}+0,30 E_{E d y}$

$A_{E d y}=0,30 E_{E d x}+E_{E d y}$

The symbol $E_{E d}$ denotes the design earthquake effect in the direction $x$ or $y$. Partial safety factors $\gamma$ are not included in the seismic design combination as the principle of design according to EN 1998-1 is based on behaviour factors q. Taking into account the possibility of two-directional earthquake action along a particular straight line, the total of eight combinations can be adopted, as shown in Table 5.

Table 5. Combinations of actions for seismic design combination

\begin{tabular}{|l|c|c|c|c|}
\hline Designation & $G_{k}$ & $Q_{k}$ & $E_{E d x}$ & $E_{E d y}$ \\
\hline Combination 1 & 1,00 & 0,30 & 1,00 & 0,30 \\
\hline Combination 2 & 1,00 & 0,30 & 1,00 & $-0,30$ \\
\hline Combination 3 & 1,00 & 0,30 & $-1,00$ & 0,30 \\
\hline Combination 4 & 1,00 & 0,30 & $-1,00$ & $-0,30$ \\
\hline Combination 5 & 1,00 & 0,30 & 0,30 & 1,00 \\
\hline Combination 6 & 1,00 & 0,30 & 0,30 & $-1,00$ \\
\hline Combination 7 & 1,00 & 0,30 & $-0,30$ & 1,00 \\
\hline Combination 8 & 1,00 & 0,30 & $-0,30$ & $-1,00$ \\
\hline
\end{tabular}




\section{Reduction of stiffness of load-bearing elements}

If for some reason (e.g. if an appropriate software is unavailable) the non-linear behaviour of a structure, and cracking of its elements during earthquake, can not be taken into account then, according to Section 4.3.1 (7) of EN 1998-1 [1], this effect can be simulated by adopting in the design reduced values of shear stiffness and flexural stiffness for load-bearing concrete and masonry elements, and this in the amount of 50 percent of the initial stiffness that is applied in the basic design combination. In this way, non-linearity is introduced while, at the same time, the behaviour factor defined for full stiffness of load bearing elements remains unchanged.

This study of influence of reduced stiffness of structural elements (beams and walls) was conducted in the interval between $100 \%$ and $10 \%$ of initial flexural stiffness of elements, using the Tower software package that enables reduction of flexural stiffness of slabs, beams and vertical curtain walls. This is understandable as, according to widely accepted rules for the design of structure in seismic areas, the reduction of stiffness is not recommended for columns $[2,9,10]$. At that, the flexural stiffness of all beams was reduced for the first structure, while the flexural stiffness of columns remained constant. In case of the second structure, the flexural stiffness of all vertical curtain walls was reduced, while the stiffness of beams and columns remained unchanged.

After earthquake, when a structure is damaged and when the stiffness of individual structural elements is reduced, the modulus of elasticity may retain the same value it had prior to the earthquake, but the flexural stiffness is reduced by taking into account damage made to the element. As a result of an earthquake action, the geometry of cross section is reduced and hence the initial moment of inertia $I_{o}$ is also modified. This moment of inertia is, together with the initial modulus of elasticity $E_{d}$ a parameter for defining the change in flexural stiffness, cf. Figure 7.
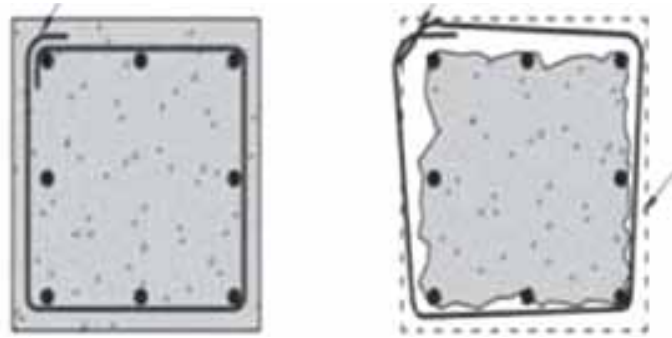

Figure 7. Undamaged cross section and the same cross section after earthquake damage (without protective layer, with fork opening)

\subsection{Comparison of section forces for the basic and seismic design combination}

Structure 1 - reduced beam stiffness

Basic system vibration period increases with the reduction of flexural stiffness of beams, i.e. circular eigen-frequencies of structuresgiven in Figure 1, Table 6, are reduced.
Table 6. Basic periods and oscillation frequencies for Structure 1

\begin{tabular}{|c|c|c|}
\hline $\begin{array}{c}\text { Beam stiffness } \\
{[\%]}\end{array}$ & $\begin{array}{c}\text { Basic period } \\
{[\mathbf{s}]}\end{array}$ & $\begin{array}{c}\text { Frequency } \\
\text { [Hz] }\end{array}$ \\
\hline 100 & 0,805 & 1,243 \\
\hline 90 & 0,820 & 1,220 \\
\hline 80 & 0,838 & 1,193 \\
\hline 70 & 0,859 & 1,164 \\
\hline 60 & 0,886 & 1,129 \\
\hline 50 & 0,922 & 1,085 \\
\hline 40 & 0,968 & 1,033 \\
\hline 30 & 1,036 & 0,965 \\
\hline 20 & 1,141 & 0,876 \\
\hline 10 & 1,340 & 0,746 \\
\hline
\end{tabular}

Internal force valuesfor typical structural elements, as based on the basic design combination, are presented in Tables 7, 8, and 9 .

Table 7. Section forces in slab subjected to greatest load, for the basic design situation

\begin{tabular}{|c|c|c|}
\hline Cross-section & $\begin{array}{c}\text { Direction } \boldsymbol{x} \\
{\left[\mathrm{kNm} / \mathrm{m}^{\prime}\right]}\end{array}$ & $\begin{array}{c}\text { Direction } \boldsymbol{y} \\
{\left[\mathrm{kNm} / \mathrm{m}^{\prime}\right]}\end{array}$ \\
\hline field & 13,83 & 14,40 \\
\hline bearing & $-25,26$ & $-29,37$ \\
\hline
\end{tabular}

Table 8. Section forces in the beam subjected to greatest load, for the basic design situation

\begin{tabular}{|l|l|c|}
\hline \multicolumn{2}{|l|}{ Internal force } & Value \\
\hline \multirow{2}{*}{ bending moment } & field & $148,04 \mathrm{kNm}$ \\
\cline { 2 - 3 } & external bearing & $-296,90 \mathrm{kNm}$ \\
\hline longitudinal force & $43,70 \mathrm{kN}$ \\
\hline transverse force & $180,55 \mathrm{kN}$ \\
\hline
\end{tabular}

Table 9. Section forces at the base of the column subjected to greatest load, for basic design situation

\begin{tabular}{|c|c|}
\hline Internal force & Value \\
\hline bending moment & $192,91 \mathrm{kNm}$ \\
\hline longitudinal force & $-3876,00 \mathrm{kN}$ \\
\hline transverse force & $70,40 \mathrm{kN}$ \\
\hline
\end{tabular}

Two typical cross-sections are analysed for slabs (field and bearing) in order to determine which design situation is relevant. 
Table 10. Change of section forces in slab field subjected to greatest load, for seismic design combination

\begin{tabular}{|c|c|c|}
\hline \multirow{2}{*}{$\begin{array}{c}\text { Beam stiffness } \\
{[\%]}\end{array}$} & \multicolumn{2}{|c|}{$\begin{array}{c}\text { Bending moment in slab field } \\
\text { [kNm/] }\end{array}$} \\
\cline { 2 - 3 } & Direction $x$ & Direction $y$ \\
\hline 100 & 12,30 & 12,42 \\
\hline 90 & 12,48 & 12,65 \\
\hline 80 & 12,72 & 12,88 \\
\hline 70 & 12,98 & 13,14 \\
\hline 60 & 13,22 & 13,43 \\
\hline 50 & 13,50 & 13,71 \\
\hline 40 & 13,83 & 14,03 \\
\hline 30 & 14,17 & 14,37 \\
\hline 20 & 14,55 & 14,76 \\
\hline 10 & 14,75 & 14,91 \\
\hline
\end{tabular}

It can be seen from calculation results presented in Table 10 that the basic design combination is relevant until the beam stiffness reduction of $40 \%$ for the direction $x$, or $30 \%$ for the direction $y$. As in this case the quantity of reinforcement obtained is less than the minimum one, the slab in the field must be reinforced by minimum reinforcement specified in EN 1992-1 and EN 1998-1 which in this case amounts to $2.91 \mathrm{~cm}^{2} / \mathrm{m}$.

Table 11. Change of section forces above the bearing of the slab subjected to greatest load, for seismic design combination

\begin{tabular}{|c|c|c|}
\hline \multirow{2}{*}{$\begin{array}{c}\text { Beam stiffness } \\
{[\%]}\end{array}$} & \multicolumn{2}{|c|}{$\begin{array}{c}\text { Bending moment on the slab bearing } \\
\text { [kNm/m'] }\end{array}$} \\
\cline { 2 - 3 } & Direction $x$ & Direction $y$ \\
\hline 100 & $-39,42$ & $-40,11$ \\
\hline 90 & $-40,34$ & $-41,05$ \\
\hline 80 & $-41,43$ & $-42,17$ \\
\hline 70 & $-42,76$ & $-43,54$ \\
\hline 60 & $-44,42$ & $-45,24$ \\
\hline 50 & $-46,58$ & $-47,44$ \\
\hline 40 & $-49,50$ & $-50,42$ \\
\hline 30 & $-53,74$ & $-54,91$ \\
\hline 20 & $-61,14$ & $-62,65$ \\
\hline 10 & $-79,45$ & $-81,42$ \\
\hline
\end{tabular}

It can be seen during analysis of cross-section of the slab above the bearing, Table 11, that the seismic design combination is relevant regardless of the reduction in beam stiffness. Positive and negative bending moments may occur above the bearing, and so this crosssection must be reinforced in the top and bottom zones. The reinforcement to be installed must in any case exceed the minimum reinforcing requirement. The dimensioning was conducted in accordance with provisions contained in EN 1992-1 taking at that into account additional ductility requirements specified in EN 1998-1.

Table 12. Change of section forces in the field of the beam subjected to greatest load, for seismic design combination

\begin{tabular}{|c|c|}
\hline $\begin{array}{c}\text { Beam stiffness } \\
{[\%]}\end{array}$ & $\begin{array}{c}\text { Bending moment in beam field } \\
{[\mathrm{kNm}]}\end{array}$ \\
\hline 100 & 121,90 \\
\hline 90 & 117,98 \\
\hline 80 & 113,90 \\
\hline 70 & 109,65 \\
\hline 60 & 105,24 \\
\hline 50 & 100,67 \\
\hline 40 & 95,96 \\
\hline 30 & 91,15 \\
\hline 20 & 86,34 \\
\hline 10 & 81,67 \\
\hline
\end{tabular}

It can be seen from Table 12 that bending moment values reduce with the reduction of flexural stiffness of the beam in the field, and hence the quantity of reinforcement also reduces. Therefore, the basic design combination would be relevant. Because of local ductility in the tensile area, the beam must be reinforced using at leastthe minimum quantity of reinforcement as specified in EN 1998-1 (6.24 cm²).

Table 13. Change of section forces above the bearing of the beam subjected to greatest load, for seismic design combination

\begin{tabular}{|c|c|}
\hline $\begin{array}{c}\text { Beam stiffness } \\
{[\%]}\end{array}$ & $\begin{array}{c}\text { Bending moment at beam bearing } \\
{[\mathrm{kNm}]}\end{array}$ \\
\hline 100 & $-577,07$ \\
\hline 90 & $-560,93$ \\
\hline 80 & $-543,06$ \\
\hline 70 & $-523,09$ \\
\hline 60 & $-500,52$ \\
\hline 50 & $-474,59$ \\
\hline 40 & $-444,14$ \\
\hline 30 & $-407,17$ \\
\hline 20 & $-359,65$ \\
\hline 10 & $-290,00$ \\
\hline
\end{tabular}


Both positive and negative bending moments may occur in the beam cross-section above the bearing, and so here also the beam must be reinforced in its top and bottom zones. These moments reduce with the reduction of flexural stiffness of the beam and, at that, the seismic design combination is relevant until the beam stiffness reduction of $11 \%$ as related to the initial stiffness. In case of traditional frame structures, columns are the most significant elements with regard to the use of seismic energy. Here, the columns are dimensioned to inclined bending with longitudinal compressive force, taking into account additional deformation of elements according to the second order theory $[6,7]$. Interaction diagrams [7] were used during the dimensioning process.

$N_{E d}{ }^{\prime \prime}=N_{E d}^{\prime}$

$M_{E d y}^{\prime \prime}=N_{E d}^{\prime \prime} \cdot e_{t o t, z}$

$M_{E d z}^{\prime \prime}=N_{E d}^{\prime \prime} \cdot e_{t o t, y}$

Table 14. Section forces in the base of the column subjected to greatest load, for seismic design combination

\begin{tabular}{|c|c|c|c|}
\hline \multirow{2}{*}{$\begin{array}{c}\text { Beam stiffness } \\
{[\%]}\end{array}$} & \multicolumn{2}{|c|}{ Bending moment [kNm] } & \multirow{2}{*}{$\begin{array}{c}\text { Longitudinal } \\
\text { force } \\
{[\mathrm{kN}]}\end{array}$} \\
\cline { 2 - 3 } & $\mathrm{M}_{\mathrm{Edy}}$ & $\mathbf{M}_{\mathrm{Edz}}$ & $-2554,10$ \\
\hline 100 & $-572,90$ & $-172,84$ & $-2552,10$ \\
\hline 90 & $-570,30$ & $-172,00$ & $-2551,10$ \\
\hline 80 & $-567,31$ & $-171,03$ & $-2549,10$ \\
\hline 70 & $-563,86$ & $-169,91$ & $-2546,70$ \\
\hline 60 & $-559,86$ & $-168,62$ & $-2543,90$ \\
\hline 50 & $-555,19$ & $-167,13$ & $-2540,50$ \\
\hline 40 & $-549,76$ & $-165,41$ & $-2536,20$ \\
\hline 30 & $-543,52$ & $-163,46$ & $-2530,50$ \\
\hline 20 & $-536,79$ & $-161,41$ & $-2521,20$ \\
\hline 10 & $-531,70$ & $-160,00$ & \\
\hline
\end{tabular}

It was revealed that in case of columns the seismic design combination is relevant for any beam stiffness reduction value, cf. Table 14.

\subsubsection{Reinforcement quantity calculation results for seismic design combination}

$50 \%$ stiffness reduction for beams - Structure 1

The difference in the quantity of reinforcement for initial beam stiffness, and during reduction of stiffnes to $50 \%$ of the initial value, is dependent on the type of the structural element and on its position within the structure. Seismic design combination values are presented below in tabular form for the following elements:

- Field and bearing of the slab subjected to greatest load (Tables $A$ and $B$ )

- Field and bearing of the beam subjected to greatest load (Tables C, D, E)

- Base of the column subjected to greatest load (Table F)

Table A. Change of bending moment and reinforcement needed in the field of the slab subjected to greatest load

\begin{tabular}{|c|c|c|c|c|}
\hline \multirow{2}{*}{$\begin{array}{c}\text { Beam stiffness } \\
{[\%]}\end{array}$} & \multicolumn{2}{|c|}{$\begin{array}{c}\text { Bending moment } \\
{\left[\mathrm{kNm} / \mathrm{m}^{\prime}\right]}\end{array}$} & \multicolumn{2}{c|}{$\begin{array}{c}\text { Reinforcement needed } \\
{\left[\mathrm{cm}^{2} / \mathrm{m}^{\prime}\right]}\end{array}$} \\
\cline { 2 - 5 } & Direction $\boldsymbol{x}$ & Direction $\boldsymbol{y}$ & Direction $\boldsymbol{x}$ & Direction $\boldsymbol{y}$ \\
\hline 100 & 12,30 & 12,42 & 1,63 & 1,76 \\
\hline 50 & 13,50 & 13,71 & 1,79 & 1,94 \\
\hline
\end{tabular}

Table B. Change of bending moment and reinforcement needed above the bearing of the slab subjected to greatest load

\begin{tabular}{|c|c|c|c|c|}
\hline \multirow{2}{*}{$\begin{array}{c}\text { Beam stiffness } \\
{[\%]}\end{array}$} & \multicolumn{2}{|c|}{$\begin{array}{c}\text { Bending moment } \\
{\left[\mathrm{kNm} / \mathrm{m}^{\prime}\right]}\end{array}$} & \multicolumn{2}{c|}{$\begin{array}{c}\text { Reinforcement needed } \\
\left.\text { [cm }{ }^{2}\right]\end{array}$} \\
\cline { 2 - 5 } & Direction $\boldsymbol{x}$ & Direction $\boldsymbol{y}$ & Direction $\boldsymbol{x}$ & Direction $\boldsymbol{y}$ \\
\hline 100 & $-39,42$ & $-40,11$ & 5,34 & 5,78 \\
\hline 50 & $-46,58$ & $-47,44$ & 6,35 & 6,89 \\
\hline
\end{tabular}

According to the above data, it can be concluded that the quantity of reinforcement in the slab increased during the $50 \%$ beam stiffness reduction, as follows:

- for the cross-section in the slab field, the quantity of reinforcement needed increased by $9.8 \%$ for the direction $x$, and by $10.2 \%$ for the direction $y$.

- for the cross-section above the slab bearing, the quantity of reinforcement needed increased by $18.9 \%$ for the direction $x$, and by $19.2 \%$ for the direction $y$.

Table C. Change of bending moment and reinforcement needed in the field of the beam subjected to greatest load

\begin{tabular}{|c|c|c|}
\hline $\begin{array}{c}\text { Beam stiffness } \\
{[\%]}\end{array}$ & $\begin{array}{c}\text { Bending moment } \\
{[\mathrm{kNm}]}\end{array}$ & $\begin{array}{c}\text { Reinforcement needed } \\
{\left[\mathrm{cm}^{2}\right]}\end{array}$ \\
\hline 100 & 121,90 & 4,33 \\
\hline 50 & 100,67 & 3,58 \\
\hline
\end{tabular}

Table D. Change of positive bending moment and reinforcement needed in the bottom zone above the bearing of the beam subjected to greatest load

\begin{tabular}{|c|c|c|}
\hline $\begin{array}{c}\text { Beam stiffness } \\
{[\%]}\end{array}$ & $\begin{array}{c}\text { Bending moment } \\
{[\mathrm{kNm}]}\end{array}$ & $\begin{array}{c}\text { Reinforcement needed } \\
{\left[\mathrm{cm}^{2}\right]}\end{array}$ \\
\hline 100 & 404,63 & 14,64 \\
\hline 50 & 302,14 & 10,92 \\
\hline
\end{tabular}


Table E. Change of negative bending moment and reinforcement needed in the top zone above the bearing of the beam subjected to greatest load,

\begin{tabular}{|c|c|c|}
\hline $\begin{array}{c}\text { Beam stiffness } \\
{[\%]}\end{array}$ & $\begin{array}{c}\text { Bending moment } \\
{[\mathrm{kNm}]}\end{array}$ & $\begin{array}{c}\text { Reinforcement needed } \\
{\left[\mathrm{cm}^{2}\right]}\end{array}$ \\
\hline 100 & $-577,07$ & 23,10 \\
\hline 50 & $-474,59$ & 18,53 \\
\hline
\end{tabular}

The following can be concluded for the beam:

- during analysis of cross-section in the beam field, the reinforcement needed was expectedly reduced for $17,3 \%$ during the $50 \%$ beam stiffness reduction. However, the reinforcement can not be reduced to the value of 3.58 $\mathrm{cm}^{2}$ from the above table because of the local ductility requirement according to which the reinforcement of 6.24 $\mathrm{cm}^{2}$ is needed based on EN 1998-1,

- in case of cross-section above the bearing, the reinforcement needed in the bottom zone was reduced by $25.3 \%$, and by $19.8 \%$ in the top zone (in this case, the savings in reinforcement are realized through reduction in flexural stiffness of the beam).

Table F. Change of bending moments and longitudinal force in the base of the column subjected to greatest load

\begin{tabular}{|c|c|c|c|}
\hline \multirow{2}{*}{$\begin{array}{c}\text { Beam } \\
\text { stiffness } \\
{[\%]}\end{array}$} & \multicolumn{2}{|c|}{ Bending moment [kNm] } & \multirow{2}{*}{$\begin{array}{c}\text { Longitudinal } \\
\text { force } \\
{[\mathrm{kN}]}\end{array}$} \\
\hline & $M_{E d y}$ & $M_{E d z}$ & \\
\hline 100 & $-572,90$ & $-172,84$ & $-2554,10$ \\
\hline 50 & $-555,19$ & $-167,13$ & $-2543,90$ \\
\hline
\end{tabular}

The following can be concluded from the data given in the last table:

- bending moment around the axis y was reduced by 3,1 \%,

- bending moment around the axis $z$ was reduced by $3,3 \%$,

- longitudinal force was reduced by $0,4 \%$,

The constant quantity of reinforcement in the cross section of the column subjected to greatest damage was adopted for the entire beam stiffness reduction interval. This quantity amounts to $63.90 \mathrm{~cm}^{2}$. The Figure 8 shows reinforcement (marked in red) in the column subjected to greatest load, according to seismic design combination $A_{s}=63,90 \mathrm{~cm}^{2}$ $(1,78 \%)$. The brown colour denotes minimum reinforcement specified according to $E C 8, A_{s .0}=36 \mathrm{~cm}^{2}(1,0 \%)$, while the blue colour denotes reinforcement obtained according to the basic design combination $A_{\text {s.min }}=20,61 \mathrm{~cm}^{2}(0,57 \%)$.

It can be concluded that, in case of the $50 \%$ initial beam stiffness, the reinforcement requirement is equal to that of the cross section without cracking, and so there are no reinforcement savings in this structural element.

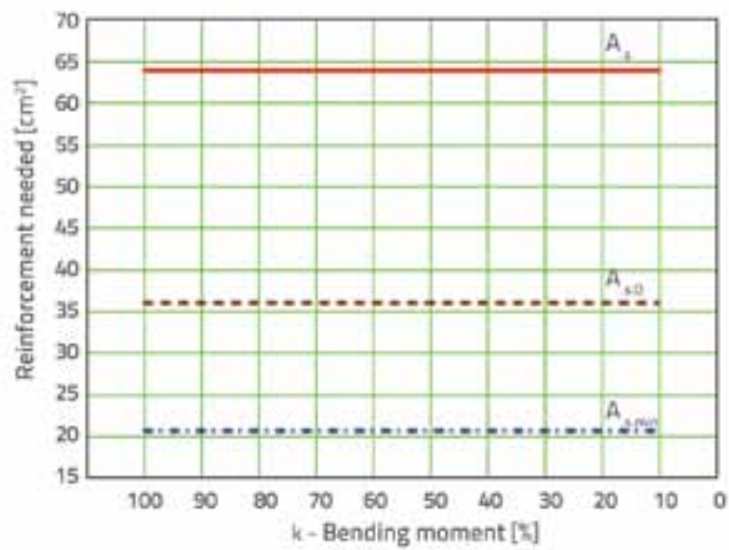

Figure 8. View of column reinforcement (red - adopted, brown minimum, blue - reinforcement for the basic combination)

\subsubsection{Calculation results for limit state of serviceability}

\section{Structure 1 - traditional frame structure}

In addition to verifications that have been presented for the ultimate limit state, it is also necessary to proceed to the analysis of the serviceability limit state (SLS) of the structure. The interstorey drift ratio (relative displacement), and the displacement at the top of the structure, are checked in the scope of the SLS analysis. The analysis will start with relative displacement verifications for the ground storey and the first storey. Relative displacements (drift values) are the most significant segment of the SLS analysis. The allowable relative displacement is obtained by means of the following expression taken from EN 1998-1:

$d_{r} \cdot v \leq 0,005 h$

where $d_{r}$ is the design interstorey drift obtained as the difference between average horizontal displacements at the top and at the bottom of the storey under study, $h$ is the storey height, and $v$ is the reduction factor that is dependent on the level of significance of the structure. The allowable relative displacement (five per mils of the height) of the ground storey and the first storey amounts to $25 \mathrm{~mm}$ and $17 \mathrm{~mm}$, respectively.

Table 15. Overview of relative displacements

\begin{tabular}{|c|c|c|}
\hline \multirow{2}{*}{$\begin{array}{c}\text { Beam stiffness } \\
{[\%]}\end{array}$} & \multicolumn{2}{|c|}{ Relative displacements [mm] } \\
\cline { 2 - 3 } & prizemlje & 1. kat \\
\hline 100 & 12,79 & 7,06 \\
\hline 90 & 12,88 & 7,29 \\
\hline 80 & 12,97 & 7,58 \\
\hline 70 & 13,10 & 7,93 \\
\hline 60 & 13,26 & 8,36 \\
\hline 50 & 13,45 & 8,91 \\
\hline 40 & 13,74 & 9,65 \\
\hline 30 & 14,16 & 10,68 \\
\hline 20 & 14,83 & 12,28 \\
\hline 10 & 16,11 & 16,22 \\
\hline
\end{tabular}


It can be seen from results given in Table 15 that the relative displacements do not exceed allowable values.

In addition to relative displacements (drifts), the analysis was also conducted for the top of the structure depending on the reduction of flexural stiffness of elements, cf. Figure 9. The allowable value of horizontal displacement at the top of the structure is determined based on the value specified in an appropriate national addendum and amounts to $H / 150(H$ is the height of the structure). This allowable displacement value is rather imprecise, which is why it is important to meet the relative displacement requirement (13). In this case, the allowable value of horizontal displacement at the top of the structure amounts to $169.33 \mathrm{~mm}$, and it is greater that the displacement at the top of the structureuntil the beam stiffness of $16 \%$ of the initial value, cf. Figure 9.

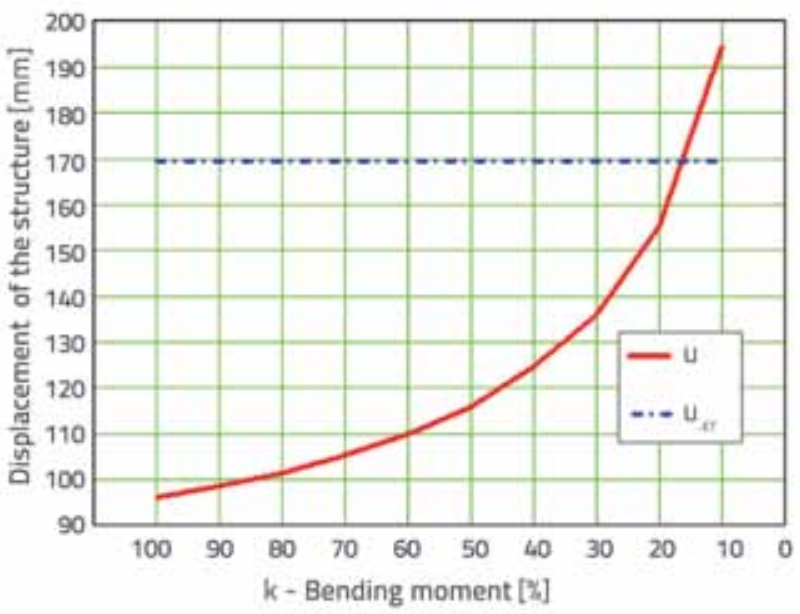

Figure 9. Dependence between the displacement at the top of the structure and its stiffness, and comparison with the allowable value

\subsection{Comparison of section forces for the basic and seismic design combinations}

\section{Reduced stiffness of vertical walls - Structure 2}

The change in flexural stiffness of reinforced-concrete walls presented in Figure 2 results in an increase of basic vibration periods of this system, i.e. circular eigen frequencies are reduced, cf. Table 16 .

In typical cross-sections of structural elements, and for the basic design combination, the design section forces amount to:
a) slab (field): $M_{E d x}=150 \mathrm{kNm} / \mathrm{m}$
b) curtain wall (base): $N_{E d}=-5015 \mathrm{kN}$
c) beam (field): $M_{E d}=-135 \mathrm{kNm}$
d) column (base): $N_{E d}=-3250 \mathrm{kN}$

Table 16. Basic periods and oscillation frequencies for Structure 2

\begin{tabular}{|c|c|c|}
\hline $\begin{array}{c}\text { Wall stiffness } \\
{[\%]}\end{array}$ & $\begin{array}{c}\text { Period } \\
{[\mathbf{s}]}\end{array}$ & $\begin{array}{c}\text { Frequency } \\
\text { [Hz] }\end{array}$ \\
\hline 100 & 0,890 & 1,124 \\
\hline 90 & 0,930 & 1,075 \\
\hline 80 & 0,971 & 1,030 \\
\hline 70 & 1,030 & 0,971 \\
\hline 60 & 1,100 & 0,909 \\
\hline 50 & 1,180 & 0,847 \\
\hline 40 & 1,250 & 0,800 \\
\hline 30 & 1,450 & 0,690 \\
\hline 20 & 1,671 & 0,598 \\
\hline 10 & 2,100 & 0,476 \\
\hline
\end{tabular}

The basic design combination is relevant in the slab bearing zone, and this regardless of the reduction in wall stiffness. Thus, the influence of vertical wall stiffness reduction on the change in flexural moment is observed in the slab field only. The basic design combination until the reduced stiffness value of $40 \%$ is relevant for slab design in the field, cf. Table 17.

Table 17. Change of section forces in the field of the slab subjected to greatest load for seismic design situation

\begin{tabular}{|c|c|}
\hline $\begin{array}{c}\text { Wall stiffness } \\
{[\%]}\end{array}$ & $\begin{array}{l}\text { Bending moment in slab field } \\
{[\mathrm{kNm} / \mathrm{m}]}\end{array}$ \\
\hline 100 & 62,00 \\
\hline 90 & 81,00 \\
\hline 80 & 92,00 \\
\hline 70 & 103,00 \\
\hline 60 & 115,00 \\
\hline 50 & 138,00 \\
\hline 40 & 147,00 \\
\hline 30 & 151,00 \\
\hline 20 & 160,00 \\
\hline 10 & 172,00 \\
\hline
\end{tabular}

In the basic design combination, the longitudinal compressive force of $N_{E d}=-5015$ is dominant in curtain walls. In the seismic design combination, which is relevant in this case, the bending 
moment also occurs, as a result of seismic action, in the base of the structure, in addition tothe longitudinal compressive force, cf. Table 18.

Table 18. Change of section forces at the base of the wall subjected to greatest load, for the seismic design situation

\begin{tabular}{|c|c|c|}
\hline $\begin{array}{c}\text { Wall stiffness } \\
{[\%]}\end{array}$ & $\begin{array}{c}\text { Longitudinal force } \\
{[\mathrm{kN}]}\end{array}$ & $\begin{array}{c}\text { Bending moment } \\
{[\mathrm{kNm}]}\end{array}$ \\
\hline 100 & -5685 & 214 \\
\hline 90 & -5613 & 201 \\
\hline 80 & -5597 & 198 \\
\hline 70 & -5524 & 185 \\
\hline 60 & -5480 & 170 \\
\hline 50 & -5387 & 157 \\
\hline 40 & -5360 & 145 \\
\hline 30 & -5285 & 132 \\
\hline 20 & -5123 & 112 \\
\hline 10 & -5049 & 95 \\
\hline
\end{tabular}

The basic design combination for each value of reduced wall stiffness in the seismic design combination is relevant for the cross section of the beam subjected to greatest load, above the bearing, cf. Table 19. Thus, in this case, the influence of the wall stiffness reduction will be observed only in relation to the change of bending moments in the field of the beam. The dimensioning of the beam in field is based on the basic design combination until the reduced wall stiffness values of less than $33 \%$, cf. Table 19.

Table 19. Change of section forces in the field for the seismic design situation

\begin{tabular}{|c|c|}
\hline $\begin{array}{c}\text { Wall stiffness } \\
{[\%]}\end{array}$ & $\begin{array}{c}\text { Bending moment } \\
{[\mathrm{kNm}]}\end{array}$ \\
\hline 100 & 65,00 \\
\hline 90 & 70,00 \\
\hline 80 & 75,00 \\
\hline 70 & 88,00 \\
\hline 60 & 90,00 \\
\hline 50 & 100,00 \\
\hline 40 & 115,00 \\
\hline 30 & 135,00 \\
\hline 20 & 150,00 \\
\hline 10 & 162,00 \\
\hline
\end{tabular}

Results obtained for columns are presented below. The longitudinal compressive force in column exceeds the value from the basic design combination at the wall stiffness of less than $30 \%$. This means that the basic design combination is also relevant for the wall stiffness reduced to $50 \%$.

\subsubsection{Reinforcement quantity calculation results for seismic design combination}

\section{Structure 2 - frame with vertical curtain walls}

Beams and slabs are dimensioned in accordance with provisions contained in EN 1992-1 taking into account additional requirements for local ductility as specified in EN 1998-1.

The quantity of reinforcement required in the design with 100 $\%$ and $50 \%$ flexural stiffness of walls is shown in Table 20.

Table 20. Overview of reinforcement required in structural elements, as related to wall stiffness reduction

\begin{tabular}{|c|c|c|}
\hline $\begin{array}{c}\text { Structural } \\
\text { element }\end{array}$ & $100 \%$ wall stiffness & $50 \%$ wall stiffness \\
\hline \multirow{2}{*}{ slab } & field: $6,72 \mathrm{~cm}^{2} / \mathrm{m}$ & field: $12,80 \mathrm{~cm}^{2} / \mathrm{m}$ \\
\cline { 2 - 4 } & bearing: $3,07 \mathrm{~cm}^{2} / \mathrm{m}$ & bearing: $5,41 \mathrm{~cm}^{2} / \mathrm{m}$ \\
\hline \multirow{2}{*}{ wall } & base: $5,26 \mathrm{~cm}^{2} / \mathrm{m}$ & base: $7,64 \mathrm{~cm}^{2} / \mathrm{m}$ \\
\cline { 2 - 4 } & centre: $7,58 \mathrm{~cm}^{2} / \mathrm{m}$ & centre: $8,95 \mathrm{~cm}^{2} / \mathrm{m}$ \\
\hline \multirow{2}{*}{ beam } & polje: $22,02 \mathrm{~cm}^{2}$ & field: $15,38 \mathrm{~cm}^{2}$ \\
\cline { 2 - 4 } & bearing: $7,46 \mathrm{~cm}^{2}$ & bearing: $10,56 \mathrm{~cm}^{2}$ \\
\hline \multirow{2}{*}{ column } & base: $11,50 \mathrm{~cm}^{2}$ & base: $13,80 \mathrm{~cm}^{2}$ \\
\cline { 2 - 4 } & & centre: $13,80 \mathrm{~cm}^{2}$ \\
\hline
\end{tabular}

If quantities of reinforcement needed for these structural elements are considered, it can be seen that the reinforcement obtained by calculation is normally greater (except in beam field) in case of $50 \%$ wall stiffness, when compared to reinforcement in case of $100 \%$ wall stiffness. This means that there is a difference in the quantity of reinforcement, and this difference further increases with the reduction in wall stiffness. The reinforcement obtained in walls is for every reduced wall stiffness value greater than the minimum one, and smaller than the maximum reinforcement.

It should also be noted that in case of the $50 \%$ wall stiffness reduction the transverse reinforcement should be distributed more densely across the wall, column and beams. In the seismic design situation the quantity of reinforcement for vertical walls is greater than the minimum value specified for each case of reduced stiffness. 


\subsubsection{Calculation results for limit state of usability}

Structure 2 - frame with vertical curtain walls Interstorey drift values (relative displacements) are the most important factor in the analysis of the SLS structural system. Their values for the ground storey and the first storey are presented in Table 21. These values are lower than the allowed ones. Permissible drift values are obtained using the expression (13).

Table 21. Overview of relative displacements (drifts) of the structure

\begin{tabular}{|c|c|c|}
\hline \multirow{2}{*}{$\begin{array}{c}\text { Wall stiffness } \\
{[\%]}\end{array}$} & \multicolumn{2}{|c|}{ Relative displacements [mm] } \\
\cline { 2 - 3 } & ground storey & 1. storey \\
\hline 100 & 21,50 & 4,08 \\
\hline 90 & 21,89 & 5,98 \\
\hline 80 & 22,03 & 7,15 \\
\hline 70 & 22,15 & 8,6 \\
\hline 60 & 22,59 & 9,8 \\
\hline 50 & 22,93 & 11,18 \\
\hline 40 & 23,58 & 12,86 \\
\hline 30 & 24,12 & 14,6 \\
\hline 20 & 25,15 & 15,8 \\
\hline 10 & 26,22 & 18,59 \\
\hline
\end{tabular}

The absolute displacement of the top of the structure is shown in Figure 10, as related to the reduced wall stiffness. For each reduced wall stiffness, such displacements are much smaller than the allowed displacement, which amounts to $333 \mathrm{~mm}$. This is directly due to the influence of vertical concrete walls.

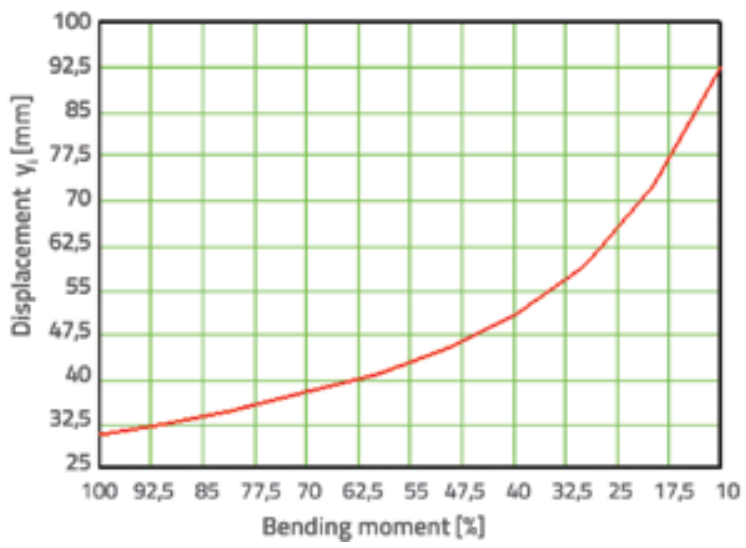

Figure 10. Change of displacement at the top of the structure as related to the reduction of the vertical wall stiffness

\subsubsection{Influence of wall stiffness reduction on the change of relevant combination}

After stiffness reduction in a structural element, section forces are redistributed into other structural elements. The redistribution of section forces is proportional to stiffness of an element. Consequently, stiffer elements assume greater part of seismic forces. If for instance the stiffness of vertical walls is reduced, then the frame system (columns and beams taken as structural elements whose stiffnesses remain unchanged) assumesa greater part of seismic forces. This is shown in Figure 11 for columns in which longitudinal compressive force increases with the reduction in wall stiffness. In case of columns, the seismic design combination assumes a smaller area during wall stiffness reduction, cf. Figure 11. Therefore, by reducing stiffness of an element, the range in which the seismic design combination of this structural element is relevant changes, because of the change of forces in that element.

Results obtained by analysingthe influence of wall stiffness reduction on the change of limit at which the basic or seismic design combination for beams (field) is applied, are shown in Figure 12.

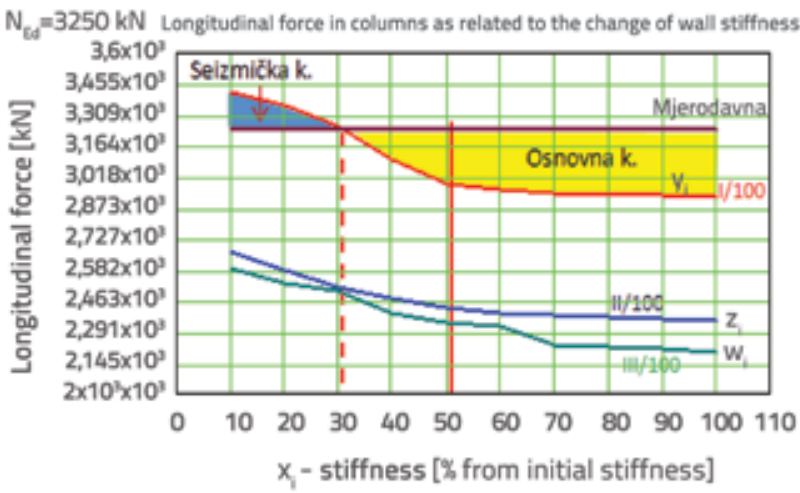

Figure 11. Change of longitudinal force in columns as related to the change of wall stiffness, and presentation of the limit stiffness of walls for the seismic and basic design combination

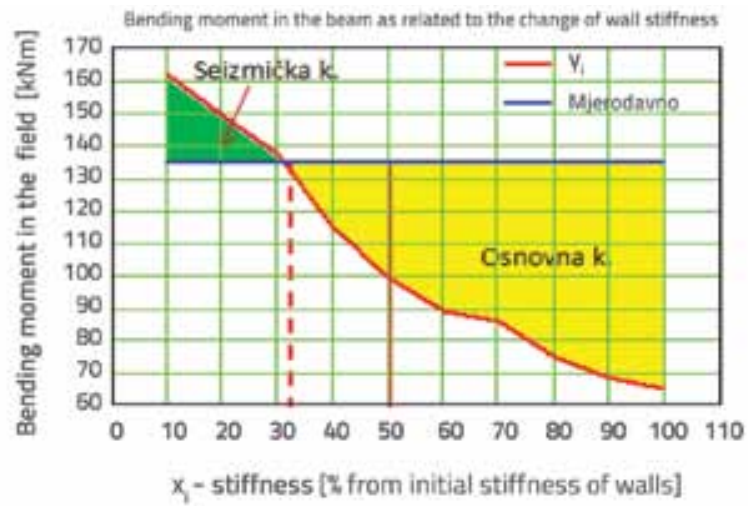

Figure 12. Change of bending moment in the beam field as related to the change of wall stiffness, and presentation of the limit stiffness of walls for the seismic and basic design combination 


\section{Conclusions}

For the first structure, the stiffness reduction results in an increase of section forces in slabs, and in adecrease of such forces in columns and beams. According to results obtained, non-fractured sections are taken for beam bearings and columns during the dimensioning of these structural elements. In this way, a greater safety of the structure as a whole is achieved. In caseof the slab field and beam cross-section in the field, the reduction of beam stiffness is of no consequence, as in these cases the minimum reinforcement defined in EN 1992-1 and EN 1998-1 is relevant. It was established that thebasic design combination for both directions is relevant for the prescribed $50 \%$ beam stiffness reduction, while the seismic design combination is relevant for cross sections above the bearings. The basic design combination is relevant for beams in the field, while the seismic design combination is relevant for columns.

As to the second structure, section forces in slabs, beams and columns increase (and the quantity of reinforcement in these elements also increases) with the reduction of the RC wall stiffness. The basic design combination is always relevant for cross-sections of slab and beam bearings, while in the field, the seismic design combination is relevant until $40 \%$ of the initial wall stiffness for slabs, i.e. $33 \%$ of the initial wall stiffness for beams. For the columns, this limit value corresponds to the $30 \%$ wall stiffness. It is recommended in EN 1998-1 that the initial wall stiffnessshould be reduced to $50 \%$ as, at this value, the seismic design combination is no longer valid, as confirmed by results for the second structure.

In the scope of analyses made in the paper, the stiffness of structural elements (beams or walls) was reduced from $100 \%$ to $10 \%$ of initial stiffness values of such elements. The limits at which the basic design combination stops being relevant, i.e. when the seismic design combination starts being relevant, is not equal for each structural element. It can be concluded from the results obtained that the change of internal forces in typical structural elements, due to reduction of stiffness of individual elements, depends on the structural system selected, on the behaviour factor adopted, and on dimensions of individual elements. Obviously, a general conclusion on reinforcement consumption as related to element stiffness reduction can not be made because, as shown in the analyses related to these two cases, the quantity and disposition of reinforcement depends on the type of the structural system. In some structural elements, the quantity of reinforcement reduces, while in other elements it increases, with the reduction of stiffness. The adoption of $50 \%$ of initial stiffness (of beams or walls) results in a more realistic seismic behaviour of structures, and the reinforcement in the structure is more evenly distributed.

The research presented inthis paper was conducted in the scope of the scientific project "Development of structures characterized by increased reliability with regard to seismic action" (114-0821466-1470), funded by the Ministry of Science, Education and Sport of the Republic of Croatia.

\section{REFERENCES}

[1] Eurocode 8 - Design of structures for earthquake resistance - Part 1: General rules, seismic actions and rules for buildings, European Committee for Standardization, CEN, Brussels, EN 1998-1: 2004

[2] Čaušević, M.: Dinamika konstrukcija - Potresno inženjerstvo, Aerodinamika, Konstrukcijske euronorme, Golden marketing Tehnička knjiga, Zagreb, 2010.

[3] Eurocode 1-Actions on structures - Part 1-1: General actions - densities, selfweight, imposed load for buildings: CEN European Committee for Standardization (ENV 1991 - 2 - 1 1995), Brussels, 1995.

[4] Eurocode 0, Basis of structural design, CEN European Committee for Standardization, Brussels, EN 1990: 2002.

[5] Eurocode 2 - Design of concrete structures - Part 1 -1: General rules and rules for buildings: CEN - European Committee for Standardization, Brussels, 2004

[6] Čaušević, M.: Statika i stabilnost konstrukcija - geometrijska nelinearnost, Školska knjiga, Zagreb, 2003.

[7] Tomičić, I.: Priručnik za proračun AB konstrukcija, DHGK, Zagreb, 1993.

[8] Eurokod 8 - Projektiranje potresne otpornosti konstrukcija - 1. dio: Opća pravila, potresna djelovanja i pravila za zgrade - Nacionalni dodatak, HRN EN 1998-1/NA, prijedlog za javnu raspravu, travanj 2011.

[9] Dowrick, D. J.: Earthquake resistant design: For Engineers and Architects, 2nd Edition, John Wiley, New York, 1987.

[10] Paulay, T. and Priestley, M. J. N.: Seismic Design of Reinforced Concrete and Masonry Buildings, John Wiley, New York, 1992. 